\title{
STRUCTURE OF $\gamma$-TiAl JOINTS IN RESISTANCE BUTT WELDING WITH APPLICATION OF INTERLAYERS
}

\author{
S.I. KUCHUK-YATSENKO, I.V. ZYAKHOR, S.V. CHERNOBAJ, \\ A.A. NAKONECHNY and M.S. ZAVERTANNY \\ E.O. Paton Electric Welding Institute, NASU \\ 11 Bozhenko Str., 03680, Kiev, Ukraine. E-mail: office@paton.kiev.ua
}

\begin{abstract}
The paper deals with the features of producing joints of an alloy based on $\gamma$-TiAl intermetallics at resistance butt welding with application of interlayers in the form of foil, differing by thickness, composition and structural state. Investigations were performed on samples of $\mathrm{Ti}-47 \mathrm{Al}-2 \mathrm{Cr}-2 \mathrm{Nb}$ (at.\%) alloy, produced by electron beam remelting, both in as-delivered (cast) condition, and after heat treatment $\left(1250{ }^{\circ} \mathrm{C}, 6 \mathrm{~h}\right)$. Used as interlayer was titanium foil with microcrystalline structure 100, 200 and $400 \mu \mathrm{m}$ thick, and nanostructured multilayered foils $\mathrm{Ti} / \mathrm{Al}(52 \mathrm{Ti}-48 \mathrm{Al}$, at.\%) and $\mathrm{Ti} / \mathrm{Co}(75 \mathrm{Ti}-25 \mathrm{Co}$, at.\%) of 30-160 $\mu \mathrm{m}$ thickness. Experiments were performed in K802 system, welding mode parameters were varied in the following ranges: 5-20 MPa pressure at heating, 20-100 MPa upset pressure, hand 5-15 mm upset value. Joint microstructure and composition were studied by optical and scanning electron microscopy and X-ray microprobe analysis. Metal strength properties in the joint zone were assessed by microhardness distribution and rupture testing. It is established that the zone of $\mathrm{Ti}-47 \mathrm{Al}-2 \mathrm{Cr}-2 \mathrm{Nb}$ alloy joints made with application of solid titanium foil demonstrates structural inhomogeneity in the form of a continuous titanium interlayer and diffusion zone between the interlayer and alloy being welded, containing linear porosity. Application of nanostructured $\mathrm{Ti} / \mathrm{Al}$ and $\mathrm{Ti} / \mathrm{Co}$ foils ensures formation of defect-free joints. Metal structure in the joint zone is fine-grained bimodal $\gamma / \gamma+\alpha_{2}$, irrespective of base metal initial structure. Remains of nanostructured foils of $\mathrm{Ti} / \mathrm{Al}$ system are present in the joint zone in the form of an interlayer of dispersed $\gamma$-TiAl intermetallic, not containing any chromium or niobium. At application of foil of Ti/Co system of eutectic composition, no chemical inhomogeneity in the form of foil transformation products is found in the butt. At rupture testing of the joints, fracture runs through the base metal of $\mathrm{Ti}-47 \mathrm{Al}-2 \mathrm{Cr}-2 \mathrm{Nb}$ alloy. Joint region of higher hardness in all the considered cases coincides with the zone of structural changes resulting from thermodeformational impact of the welding process. 21 Ref., 11 Figures.
\end{abstract}

Keywords: resistance butt welding, titanium aluminide, interlayer, nanostructured multilayer foil, welded joint

One of the urgent problems is development of methods of technological processing and producing permanent joints of intermetallic titanium alloys, in particular, gamma-alloys based on $\gamma$ TiAl titanium aluminide. Gamma-alloys have high values of heat resistance (at $700-750{ }^{\circ} \mathrm{C}$ ) and oxidation resistance at relatively low density $\left(3850 \mathrm{~kg} / \mathrm{m}^{3}\right)$ [1-3]. Depending on purity and microstructure, mechanical properties of TiAl intermetallic vary in broad ranges and are equal to $\sigma_{\mathrm{t}}=350-580 \mathrm{MPa}, \delta=0.5-1.5 \%, E=$ $=175 \mathrm{MPa}, G=65 \mathrm{GPa}$. It is proposed to apply gamma-alloys for manufacturing car engine valves, and aircraft engine parts operating at high temperatures $[4,5]$.

One of the causes, limiting application of titanium aluminides, is their poor adapatibilityto-fabrication, in particular, difficulty of welding them, because of their extremely low ductility, and high sensitivity to cracking at thermode- formational impact. Joints produced in nonconsumable arc welding [6] and electron beam welding [7] are prone to cracking, which develops along the fusion line or in the HAZ. To lower the probability of cracking in titanium aluminide joints at application of fusion welding processes, preheating of the structure being welded to high temperature is required [8].

In press welding of $\gamma$-TiAl intermetallic alloy [9], welded joints feature a low strength because of formation of brittle stringers in the joint zone. The main problems in producing sound joints of titanium aluminides in friction welding $[10,11]$ is microcracking in the thermomechanical impact zone (TMIZ) during deformation and at cooling. At vacuum diffusion welding (VDW) of $\mathrm{Ti}^{-}$ $48 \mathrm{Al}-2 \mathrm{Nb}-2 \mathrm{Mn}$ alloy the interface is clearly defined and defects in the form of micropores are observed in the transition zone structure [12].

Low ductility of intermetallic alloys necessitates longer heating and increasing the thermodeformational parameters of VDW process. Formation of titanium aluminide joints without metal- 
lographically detectable defects at VDW is achieved through long soaking under pressure at the temperature of $1100-1200{ }^{\circ} \mathrm{C}$ and subsequent high-temperature heat treatment [12, 13].

Intermetallic alloy sensitivity to thermodeformational welding cycle is driving technologists to look for the ways to facilitate the conditions of activation of the surfaces being welded, primarily due to intensification of the process of local plastic deformation and acceleration of diffusion processes in the contact zone. The main technique in pressure welding processes is application of interlayers from various materials. For instance, at VDW the conditions for activation of the surfaces being welded are greatly facilitated at introduction of interlayers from ductile materials between them: aluminium, copper, nickel, titanium [9, 14]. A problem in the processes of pressure welding with application of an interlayer from different metals is formation of chemical inhomogeneity in the welded joint [9].

The effect of simultaneous increase of deformation intensity and acceleration of diffusion processes in the contact zone is achieved through application of interlayers from vacuum condensates based on multilayer structures, consisting from elements with a high reactivity [15-18]. It is shown that the lowest chemical inhomogeneity in the butt is provided by multilayer nanostructured foils (NF) of $\mathrm{Ti} / \mathrm{Al}$ system produced by the process of electron beam evaporation and deposition of the vapour phase in vacuum [18]. So, VDW of $\gamma$-TiAl base alloy with application of $\mathrm{NF}$ of $\mathrm{Ti} / \mathrm{Al}$ system provides formation of sound joints $[16,17]$ with the strength close to base material (BM) values. Positive influence of $\mathrm{NF}$ application at VDW is associated with intensification of mass transfer processes in the zone of contact, owing to running of the reaction of self-propagating high-temperature synthesis (SHS) [19].

VDW application is limited by the need to heat the entire item being welded up to considerable temperatures in the vacuum chamber, extremely high requirements to preparation of surfaces being welded and low efficiency of the welding process. Therefore, an urgent issue is studying the applicability of pressure welding processes providing higher efficiency and possibility of sound joining of various materials without application of shielding medium or vacuum.

Such pressure welding processes include resistance butt welding (RBW). In [20] joint formation at RBW of $\mathrm{Ti}-47 \mathrm{Al}-1.5 \mathrm{Cr}-2 \mathrm{Nb}$ alloy produced by electron beam remelting technology was studied. It is found that application of NF of
$\mathrm{Ti} / \mathrm{Al}$ system allowed an essential improvement of joint formation, reducing sample upset value and RBW process duration. Positive effect was achieved owing to a more concentrated evolution of heat in the contact zone due to running of SHS reaction in NF. NF application allowed reducing the heat input, localizing deformation in the contact zone and avoiding cracking. However, a considerable hardness gradient is observed in the joints: microhardness value rises by $60 \%$, compared to BM values [20]. At mechanical testing fracture runs in the transition zone between TMIZ and BM of the cast alloy. It can be assumed that this zone features a combination of the high level of welding stresses and extremely low ductility of metal of $\gamma$-TiAl cast alloy with coarsecrystalline plate-like structure.

Obtained results show the good prospects for NF application as activators of the process of RBW of titanium intermetallic alloys. Investigations of the influence of NF composition and thickness, as well as initial structure of the alloy being welded on joint formation, are urgent for further improvement of RBW technology.

The objective of the work is to establish the features of formation of joint structure of $\gamma$-TiAl alloy in different initial condition at RBW with application of interlayers, differing by their composition, structural state and thickness.

Investigation procedure. Investigations were performed on samples of $\mathrm{Ti}-47 \mathrm{Al}-2 \mathrm{Cr}-2 \mathrm{Nb}$ (at.\%) alloy produced by electron beam remelting (samples of square section of $10 \times 10 \mathrm{~mm}$ ). The first batch of samples was welded in asdelivered condition, and the second was annealed at the temperature in $(\alpha+\gamma)$-region $\left(1250{ }^{\circ} \mathrm{C}, 6 \mathrm{~h}\right)$ before conducting RBW that resulted in coarse-crystalline plate-like structure of the cast alloy transforming into completely granular structure, differing by higher ductility values [2].

Used as interlayer at RBW were foils of three types, differing by composition and structural state: titanium foil with microcrystalline structure and nanolayered foils: $\mathrm{Ti} / \mathrm{Al}(52 \mathrm{Ti}-48 \mathrm{Al}$, at.\%) and $\mathrm{Ti} / \mathrm{Co}(75 \mathrm{Ti}-25 \mathrm{Co}$, at.\%) (Figure 1). Foil thickness was as follows: titanium -100 , 200 and $400 \mu \mathrm{m}, \mathrm{Ti} / \mathrm{Al} \mathrm{NF}-30,60$ and $160 \mu \mathrm{m}$, $\mathrm{Ti} / \mathrm{Co} \mathrm{NF}-100 \mu \mathrm{m}$. Difference in foil composition predetermines the difference in their melting temperature $T_{\text {melt }}$, compared to $T_{\text {melt }}$ of the alloy being welded: higher (titanium foil with $\left.T_{\text {melt }}=1668{ }^{\circ} \mathrm{C}\right)$, equal $(\mathrm{Ti} / \mathrm{Al} \mathrm{NF}$ transformed at heating into TiAl intermetallic with $T_{\text {melt }}=$ $\left.=1460{ }^{\circ} \mathrm{C}\right)$ and lower $(\mathrm{Ti} / \mathrm{Co} \mathrm{NF}$ transformed into an eutectic with $T_{\text {melt }}=1170{ }^{\circ} \mathrm{C}$ ). 
Experiments on RBW were conducted in a laboratory set-up, based on K802 welding machine. Current value and compression force were regulated by computerized control system. Range of process parameter variation was optimized on the basis of preliminary experiments so as to provide the specified deformation (upset value) in welding all sample batches. RBW parameters were varied in the following ranges: 5-20 MPa pressure at heating, 20-100 $\mathrm{MPa}$ upset pressure, and $5-15 \mathrm{~mm}$ upset value.

Welding quality was assessed by a comprehensive testing procedure [21], envisaging application of computerized on-line control of welding mode parameters, techniques of welded joint NDT and metallographic examination. Welded joint microstructure and composition was studied by optical microscopy (Neophot-32), scanning electron microscopy (JEOL JSM-35SA) and Xray microprobe analysis (EDS-analyzer INCA450 of Oxford Instruments with probe diameter of about $1 \mu \mathrm{m}$ ). Strength properties were evaluated by microhardness distribution (LECO microhardness meter M400) at $2 \mathrm{~N}$ load.

Investigation results. It is established that at RBW of $\mathrm{Ti}-47 \mathrm{Al}-2 \mathrm{Cr}-2 \mathrm{Nb}$ cast alloy with completely lamellar structure defects such as lacksof-penetration and linear porosity were observed in the joint zone. Defect formation at RBW without interlayer application was observed at process parameters variation in the entire studied range, and was due to high deformation resistance and low ductility of intermetallic alloy. In welding of samples after preliminary heat treatment, joint formation conditions were improved, apparently, due to higher ductility values of the alloy with completely granular structure; however, defect formation could not be avoided (Figure 2, $a$ ).

Figure $2, b$ shows microstructure of the zone of $\mathrm{Ti}-47 \mathrm{Al}-2 \mathrm{Cr}-2 \mathrm{Nb}$ alloy joint, made with application of an interlayer in the form of titanium foil. No cracks, lacks-of-penetration, or oxide films were found in the joint structure. Irrespective of applied foil thickness (in the range of 100-400 $\mu \mathrm{m}$ ), however, the joint zone demonstrates chemical inhomogeneity in the form of a continuous titanium interlayer.

Presence of titanium foil in the contact zone at $\mathrm{RBW}$ of $\mathrm{Ti}-47 \mathrm{Al}-2 \mathrm{Cr}-2 \mathrm{Nb}$ alloy promotes localization of plastic deformation, activation of surfaces being welded and formation of defectfree joints. However, complete pressing out of titanium interlayer from the butt is not observed, even at maximum values of force and upset in the studied range. Performance of postweld heat treatment of the joints $\left(1150{ }^{\circ} \mathrm{C}, 6 \mathrm{~h}\right)$ does not completely eliminate chemical inhomogeneity.

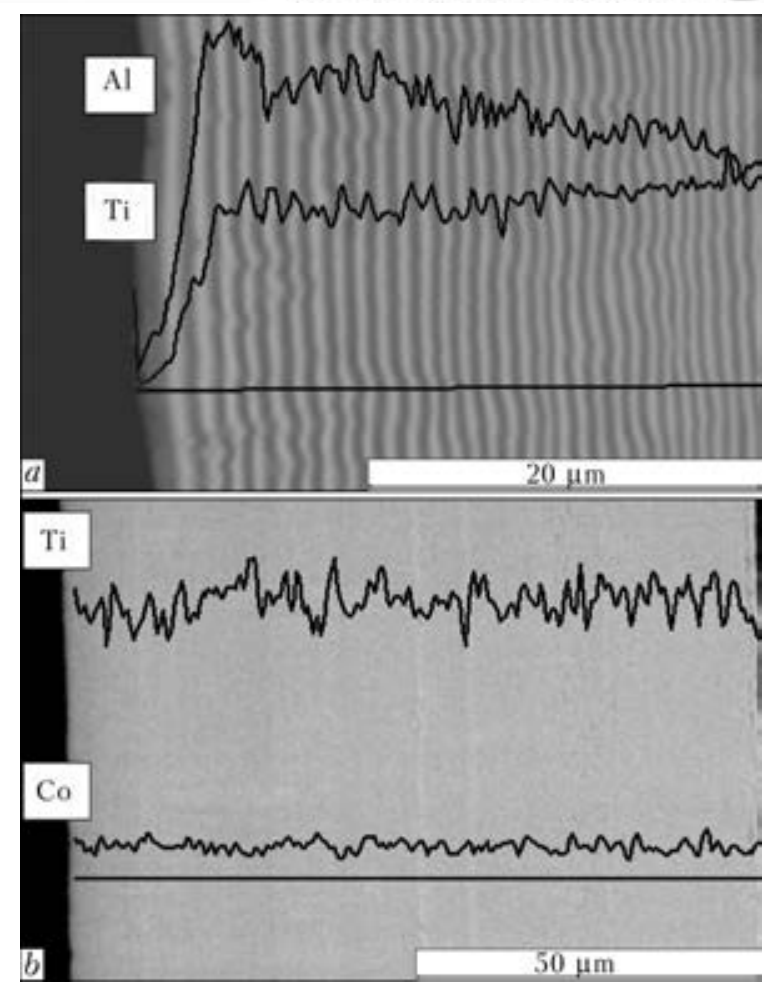

Figure 1. Microstructure of nanostructured multilayer $\mathrm{Ti} / \mathrm{Al}(a)$ and $\mathrm{Ti} / \mathrm{Co}(b)$ foils

Moreover, it leads to formation of a diffusion zone between titanium interlayer and $\gamma$-TiAl alloy BM (Figure 3). Width of titanium interlayer is equal to $40-50 \mu \mathrm{m}$, that of diffusion zone with varying concentration of $\mathrm{Ti}, \mathrm{Al}, \mathrm{Cr}, \mathrm{Nb}$ is about $25 \mu \mathrm{m}$. Diffusion zone contains linear porosity (Figure 3,a). By the data of X-ray microprobe analysis the total width of the zone of concentrational variations is equal to about $100 \mu \mathrm{m}$ ( $\mathrm{Fi}^{-}$ gure $3, b)$. Development of chemical inhomogeneity cannot be avoided at RBW of either cast or pre-heat treated $\mathrm{Ti}-47 \mathrm{Al}-2 \mathrm{Cr}-2 \mathrm{Nb}$ alloy.

Microstructure of welded joint of $\mathrm{Ti}-47 \mathrm{Al}-$ $2 \mathrm{Cr}-2 \mathrm{Nb}$ cast alloy (without preliminary heat treatment) made with application of $\mathrm{Ti} / \mathrm{Al} \mathrm{NF}$ of $\delta=60 \mu \mathrm{m}$ is given in Figure 4. No defects of any kind, including pores, were found in the joint zone. Structural changes in the joint cover a zone of total width of about $2.5 \mathrm{~mm}$ (Figure 4, $a$ ). Coarse-crystalline completely plate-like structure of BM cast alloy is transformed into finegrained bimodal (mixed) structure in the joint zone, containing dispersed products of SHS reaction in NF. Single-phase grains of $\gamma$-phase (Figure $4, d$ ) are surrounded by $\gamma+\alpha_{2}$ two-phase regions with plate-like structure.

Width of the zone of $\mathrm{Ti}, \mathrm{Al}, \mathrm{Cr}, \mathrm{Nb}$ concentrational changes is about $50 \mu \mathrm{m}$ (Figure 5, a) that is indicative of presence of dispersed products of SHS reaction in NF. Structure of the zone of transition from TMIZ to BM is almost plate- 


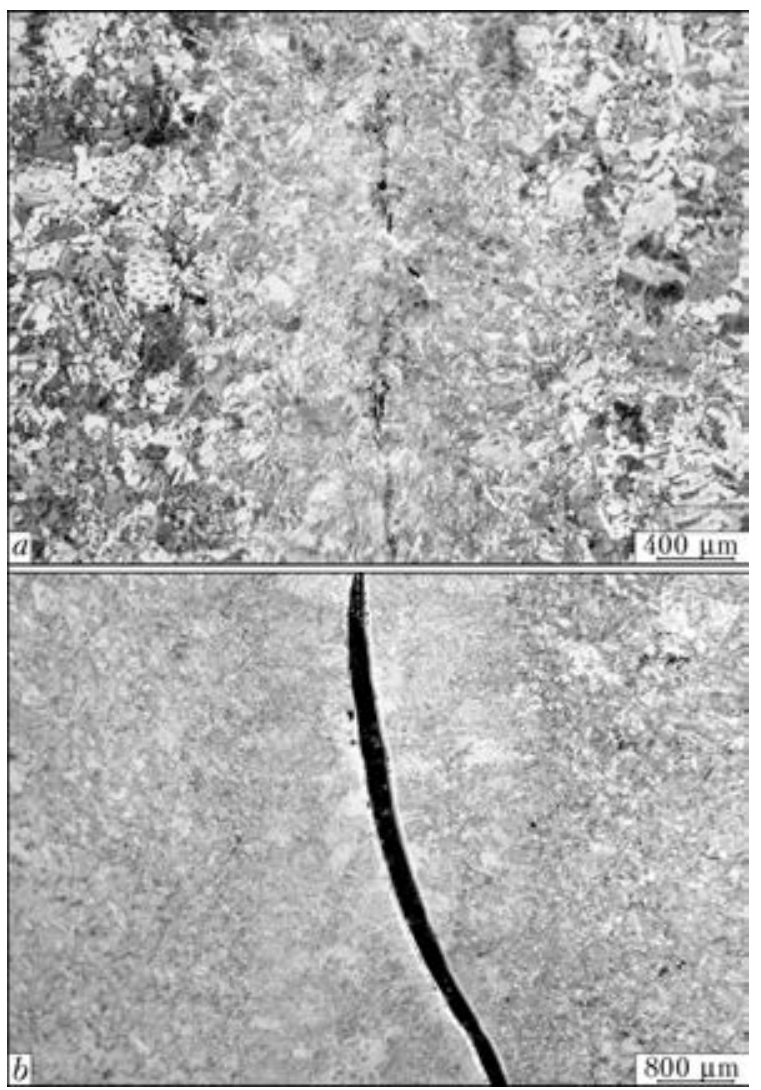

Figure 2. Microstructure of $\mathrm{Ti}-47 \mathrm{Al}-2 \mathrm{Cr}-2 \mathrm{Nb}$ alloy joint at RBW without an interlayer $(a)$ and with application of titanium foil of $\delta=400 \mu \mathrm{m}(b)$

like. Analysis of joint microstructure is indicative of completion of SHS reaction in NF across the entire cross-section of billets being welded and incomplete pressing-out of NF transformation products from the butt during RBW. Values of metal microhardness (Figure $5, b$ ) in the joint zone (HV2-4800-5660 $\mathrm{MPa})$ are much higher than those for BM alloy ( $H V 2-3700-4300 \mathrm{MPa})$. Joint region of higher hardness coincides with the zone of structural changes as a result of thermodeformational impact of RBW process, that

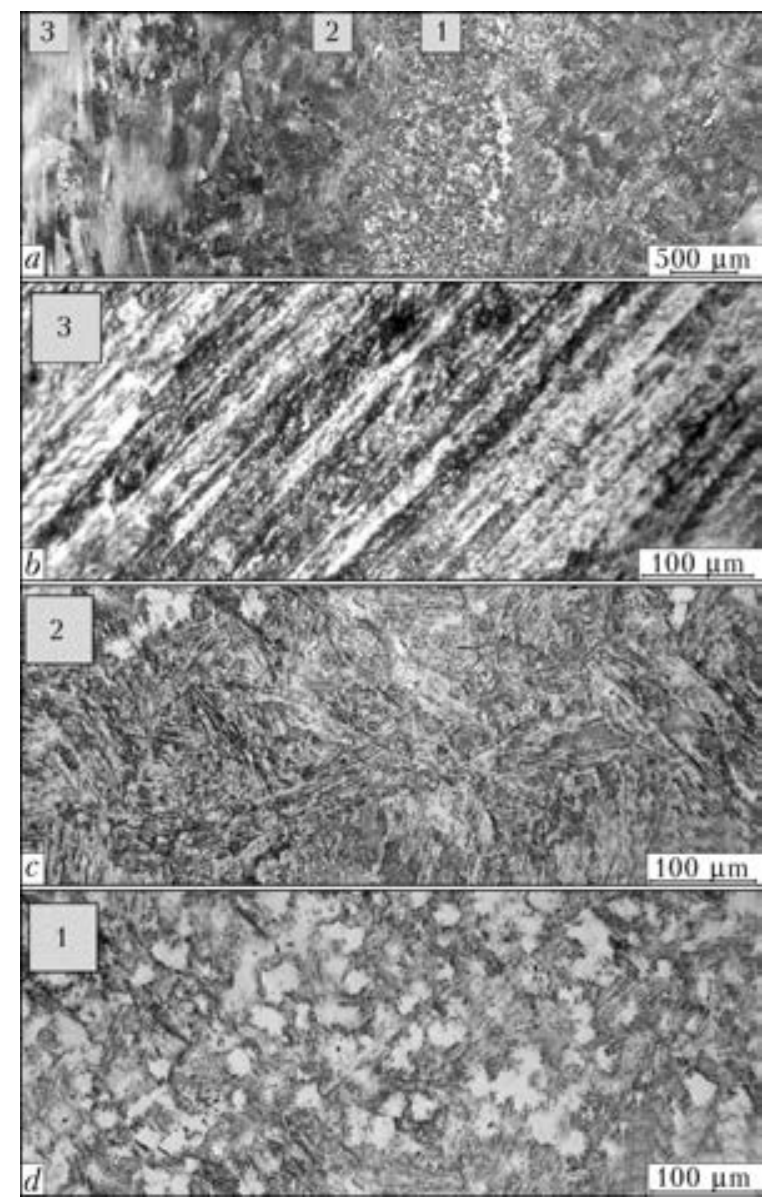

Figure 4. Microstructure of joint of $\mathrm{Ti}-47 \mathrm{Al}-2 \mathrm{Cr}-2 \mathrm{Nb}$ cast alloy at RBW with application of $\mathrm{Ti} / \mathrm{Al} \mathrm{NF}$ of $\delta=60 \mu \mathrm{m}$ : $a-$ general view; $b-\mathrm{BM} ; c-$ transition zone; $d-$ fine-grained zone

may be indicative of the contribution of hightemperature plastic deformation into changing of alloy mechanical properties. Thus, at RBW of $\mathrm{Ti}-47 \mathrm{Al}-2 \mathrm{Cr}-2 \mathrm{Nb}$ cast alloy with application of $\mathrm{Ti} / \mathrm{Al} \mathrm{NF}$ of $\delta=60 \mu \mathrm{m}$, formation of defect-free joints is ensured at considerable hardness gradient $(H V 2-1100-1300 \mathrm{MPa})$ in TMIZ.
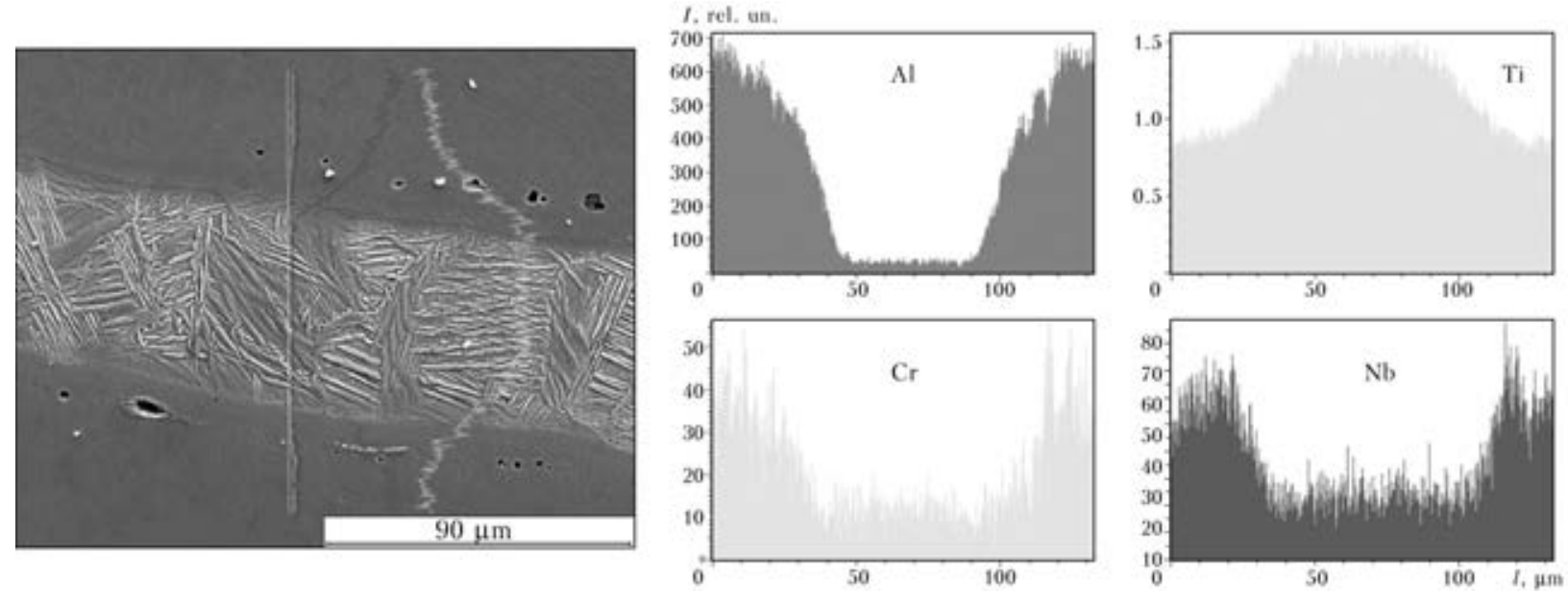

Figure 3. Microstructure and distribution of $\mathrm{Ti}, \mathrm{Al}, \mathrm{Cr}, \mathrm{Nb}$ in the joint of $\mathrm{Ti}-47 \mathrm{Al}-2 \mathrm{Cr}-2 \mathrm{Nb}$ alloy at $\mathrm{RBW}$ with application of titanium foil of $\delta=100 \mu \mathrm{m}$ (SEM) 
Microstructure of the joint of pre-heat treated $\mathrm{Ti}-47 \mathrm{Al}-2 \mathrm{Cr}-2 \mathrm{Nb}$ alloy made by RBW with application of $\mathrm{Ti} / \mathrm{Al} \mathrm{NF}$ of $\delta=60 \mu \mathrm{m}$ is shown in Figure 6, $a$. Nature of structural changes in the joint zone is similar to that found in the previous case with the difference that BM initial granular structure transforms into fine-grained bimodal structure (Figure $7, a$ ). Width of the zone of Ti, $\mathrm{Al}, \mathrm{Cr}, \mathrm{Nb}$ concentrational changes in the joint is equal to about $40 \mu \mathrm{m}$. Values of metal microhardness in the joint zone (HV3-4300$4700 \mathrm{MPa}$ ) are also higher than those for BM alloy ( $H V$ V3-3500-3800 MPa). Joint region of higher hardness coincides with thermodeformational impact zone. Transition zone structure is bimodal, unlike almost plate-like structure of transition zone of cast alloy joint. Hardness gradient in the joint zone is equal to $H V 2-800-900$ $\mathrm{MPa}$ that is somewhat lower compared to that in cast alloy welding.

Joint structure at RBW of heat-treated $\mathrm{Ti}-$ $47 \mathrm{Al}-2 \mathrm{Cr}-2 \mathrm{Nb}$ alloy with application of $\mathrm{Ti} / \mathrm{Al}$ NF of $\delta=160 \mu \mathrm{m}$ (Figure $6, b$ ) is similar. Selection of such foil is due to technological considerations - application of NF of greater thickness allows lowering the requirements to preparation
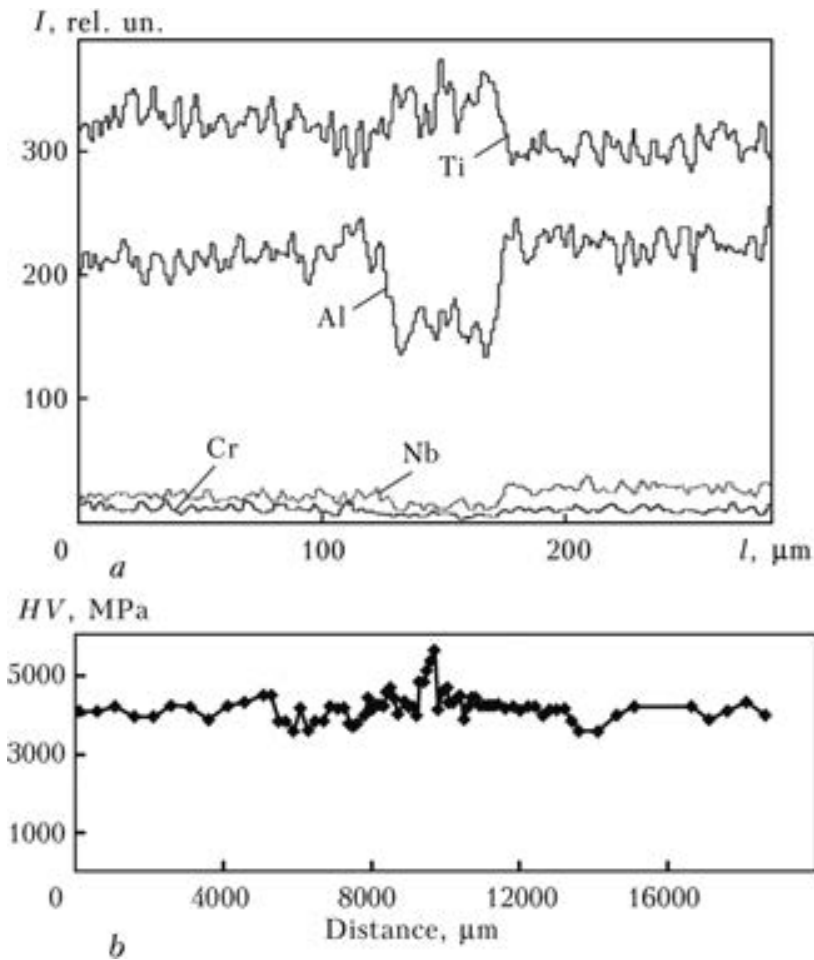

Figure 5. Distribution of $\mathrm{Ti}, \mathrm{Al}, \mathrm{Cr}, \mathrm{Nb}(a)$ and metal microhardness $(b)$ in the joint zone of $\mathrm{Ti}-47 \mathrm{Al}-2 \mathrm{Cr}-2 \mathrm{Nb}$ cast alloy produced by RBW with application of $\mathrm{Ti} / \mathrm{Al} \mathrm{NF}$ of $\delta=60 \mu \mathrm{m}$
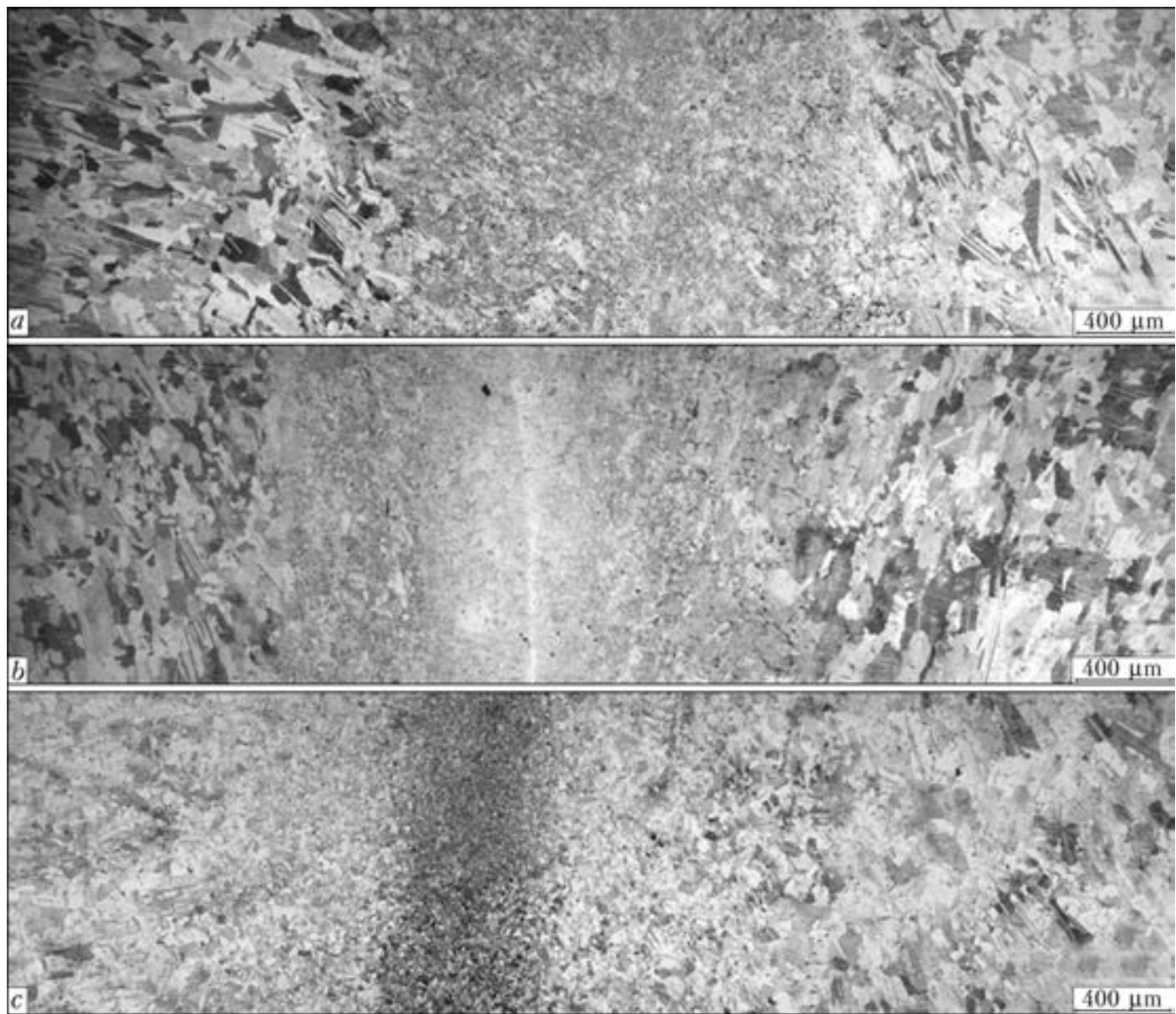

Figure 6. Microstructure of heat-treated $\mathrm{Ti}-47 \mathrm{Al}-2 \mathrm{Cr}-2 \mathrm{Nb}$ alloy joint at $\mathrm{RBW}$ with application of $\mathrm{NF}$ of $\mathrm{Ti} / \mathrm{Al}$ of $\delta=$ $=60 \mu \mathrm{m}(a), \mathrm{Ti} / \mathrm{Al}$ of $\delta=160 \mu \mathrm{m}(b)$ and $\mathrm{Ti} / \mathrm{Co}$ of $\delta=100 \mu \mathrm{m}(c)$ 


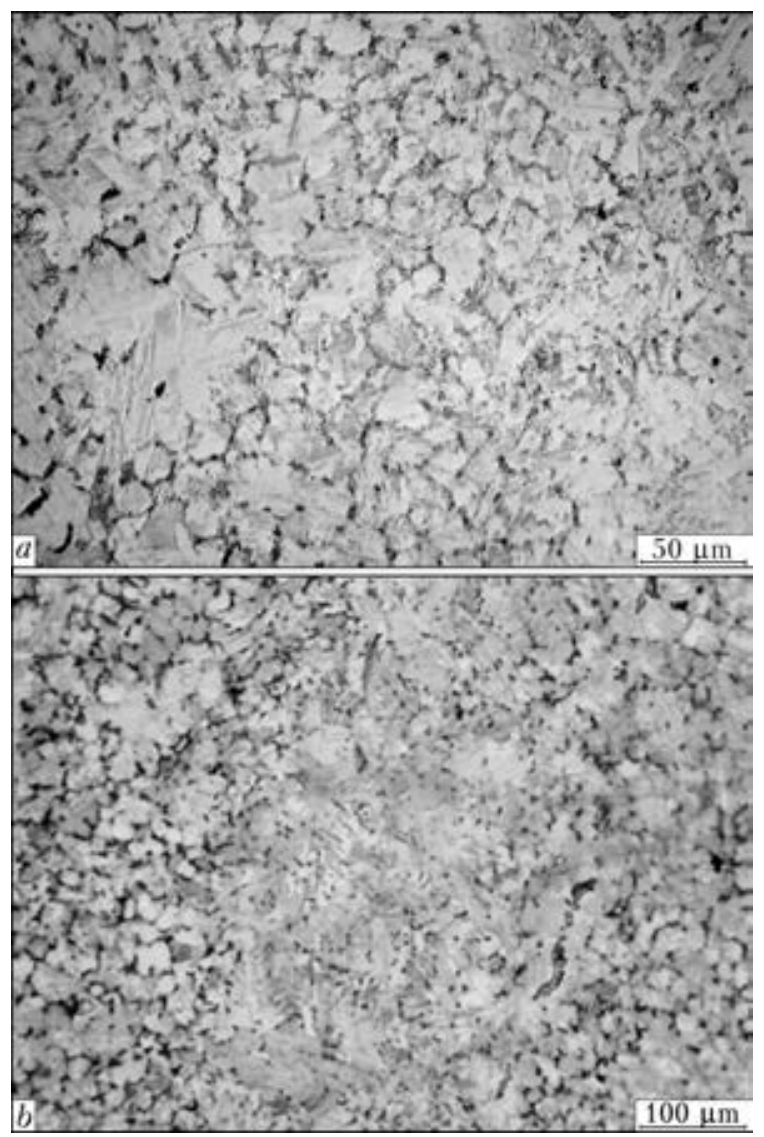

Figure 7. Metal microstructure in fine-grained zone of heattreated $\mathrm{Ti}-47 \mathrm{Al}-2 \mathrm{Cr}-2 \mathrm{Nb}$ alloy joint at RBW with application of $\mathrm{NF}$ of $\mathrm{Ti} / \mathrm{Al}$ of $\delta=60 \mu \mathrm{m}(a)$ and $\mathrm{Ti} / \mathrm{Al}$ of $\delta=$ $=160 \mu \mathrm{m}(b)$

of surfaces being welded at RBW of billets of large cross-sections. Increase of thickness of NF applied at specified RBW mode leads to greater width of the zone of $\mathrm{Ti}, \mathrm{Al}, \mathrm{Cr}, \mathrm{Nb}$ concentrational changes, which in this case is equal to about $120 \mu \mathrm{m}$. Nature of microhardness variation in the joint zone is similar to the previous case.

Structural changes in the joint of heat-treated $\mathrm{Ti}-47 \mathrm{Al}-2 \mathrm{Cr}-2 \mathrm{Nb}$ alloy, made with application of $\mathrm{Ti} / \mathrm{Co} \mathrm{NF}$ of eutectic composition, cover a zone of not more than $2 \mathrm{~mm}$ total width (see Figure $6, c)$. Metal in the joint plane, transition zone and BM has bimodal $\gamma / \gamma+\alpha_{2}$ structure with structural element size of about 15,35 and $110 \mu \mathrm{m}$, respectively (Figure 8). Unlike joints made by RBW with application of $\mathrm{Ti} / \mathrm{Al} \mathrm{NF}$, no $\mathrm{Ti} / \mathrm{Co} \mathrm{NF}$ transformation products are found in the butt joint at X-ray microprobe analysis (Figures 9 and 10). Element concentration across and along the joint zone corresponds to this value for $\mathrm{Ti}-47 \mathrm{Al}-2 \mathrm{Cr}-2 \mathrm{Nb} \mathrm{BM}$ alloy. It can be assumed that during billet deformation at RBW the forming liquid phase of eutectic composition under the conditions of compression and passage of high-power current pulses is totally pressed-
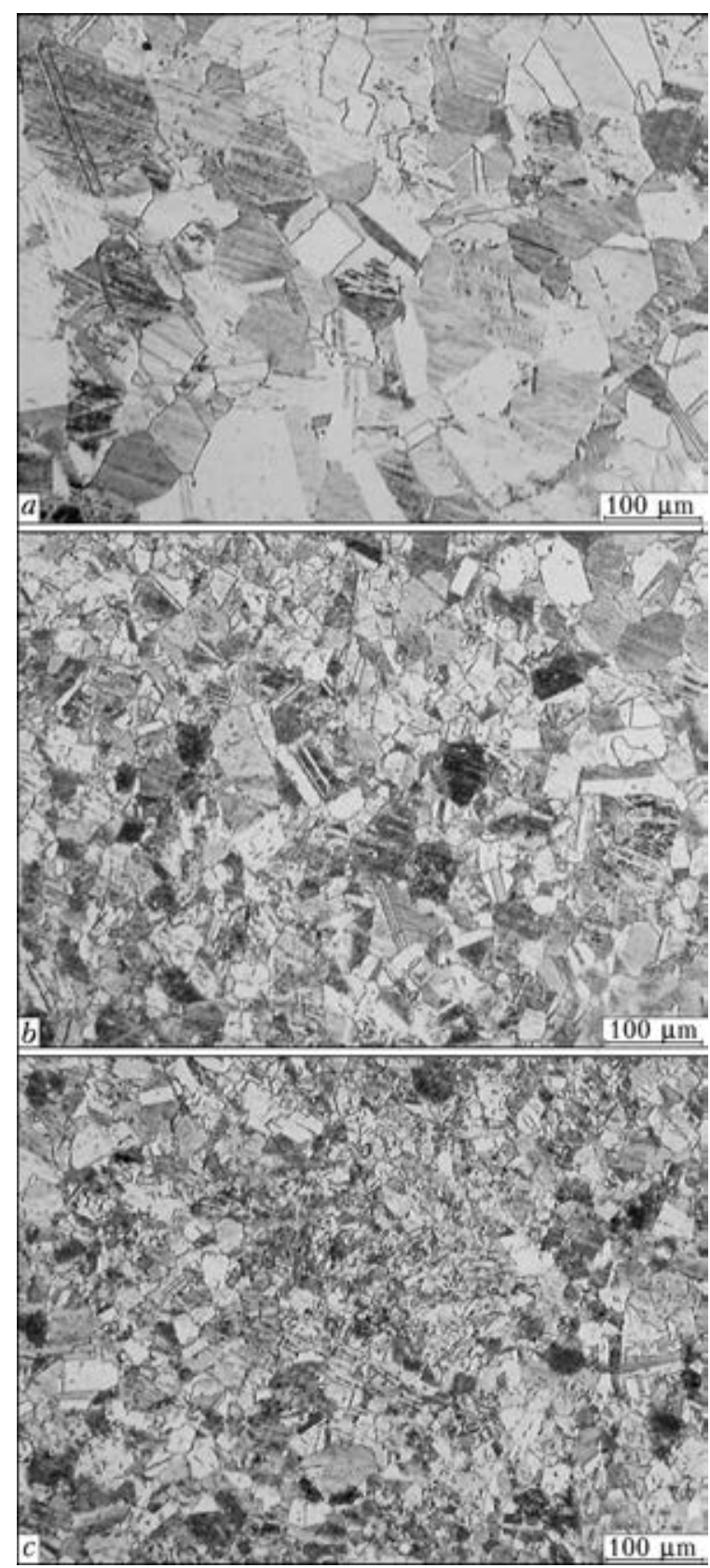

Figure 8. Microstructure of heat-treated $\mathrm{Ti}-47 \mathrm{Al}-2 \mathrm{Cr}-2 \mathrm{Nb}$ alloy joint at RBW with application of $\mathrm{Ti} / \mathrm{Co} \mathrm{NF}$ of $\delta=$ $=100 \mu \mathrm{m}: a-\mathrm{BM} ; b-$ transition zone; $c-$ fine-grained zone

out of the butt together with near-contact volumes of the alloy being welded.

Positive role of appearance of liquid phase of eutectic composition during RBW is, apparently, manifested, firstly, in local increase of specific electric resistance of metal in the contact zone that allows localization and intensification of shear plastic deformation; and, secondly, in considerable increase of mass transfer rate on liquidsolid interface. Presence of hardness gradient of HV2-700-900 $\mathrm{MPa}$ in the joint zone, similar to the previous cases, is indicative of the role of high-temperature plastic deformation in the 

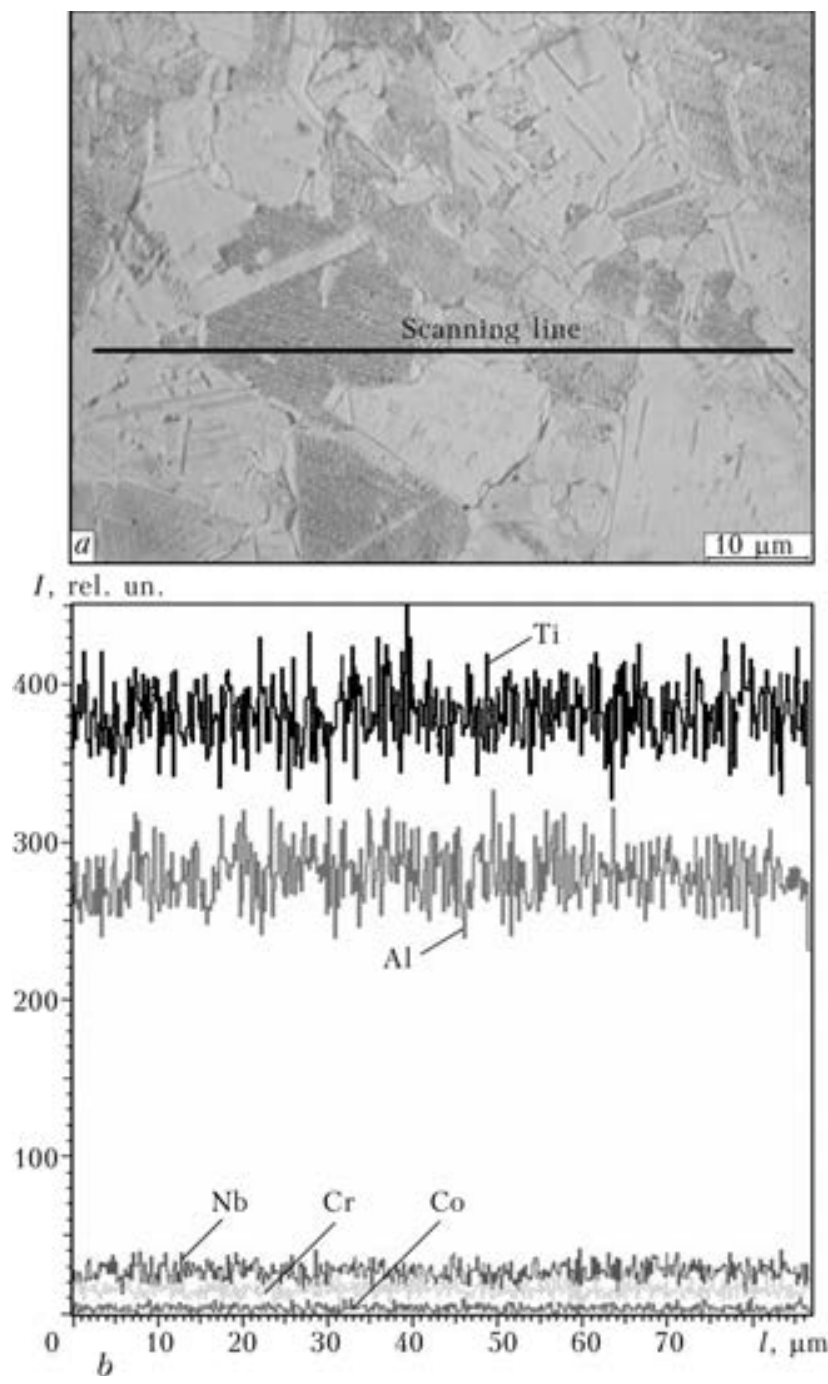

Figure 9. Microstructure $(a)$ and $\mathrm{Ti}, \mathrm{Al}, \mathrm{Cr}, \mathrm{Nb}, \mathrm{Co}$ distribution $(b)$ in metal of $\mathrm{Ti}-47 \mathrm{Al}-2 \mathrm{Cr}-2 \mathrm{Nb}$ alloy joint zone at RBW with application of $\mathrm{Ti} / \mathrm{Co} \mathrm{NF}$ of $\delta=100 \mu \mathrm{m}$

change of intermetallic alloy mechanical properties. At rupture testing of joints fracture runs through $\mathrm{BM}$ of $\mathrm{Ti}-47 \mathrm{Al}-2 \mathrm{Cr}-2 \mathrm{Nb}$ alloy $(\mathrm{Fi}-$ gure 11).

Analysis of the studied joint microstructure shows that at RBW of $\mathrm{Ti}-47 \mathrm{Al}-2 \mathrm{Cr}-2 \mathrm{Nb}$ alloy with application of $\mathrm{Ti} / \mathrm{Al} \mathrm{NF}$ transforming into $\gamma$-TiAl intermetallic during welding, metal in the joint zone has fine-grained bimodal $\gamma / \gamma+\alpha_{2}$ structure, irrespective of $\mathrm{BM}$ initial structure. Increase of applied NF thickness at preset RBW mode leads to greater width of the zone of $\mathrm{Ti}$, $\mathrm{Al}, \mathrm{Cr}, \mathrm{Nb}$ concentrational changes in the joint zone.

Joint region of higher hardness coincides with the zone of structural changes resulting from thermodeformational impact of RBW process, and is practically independent on NF thickness. Microstructure and value of hardness gradient of metal in the zone of transition from BM to finegrained region is determined by the structure of

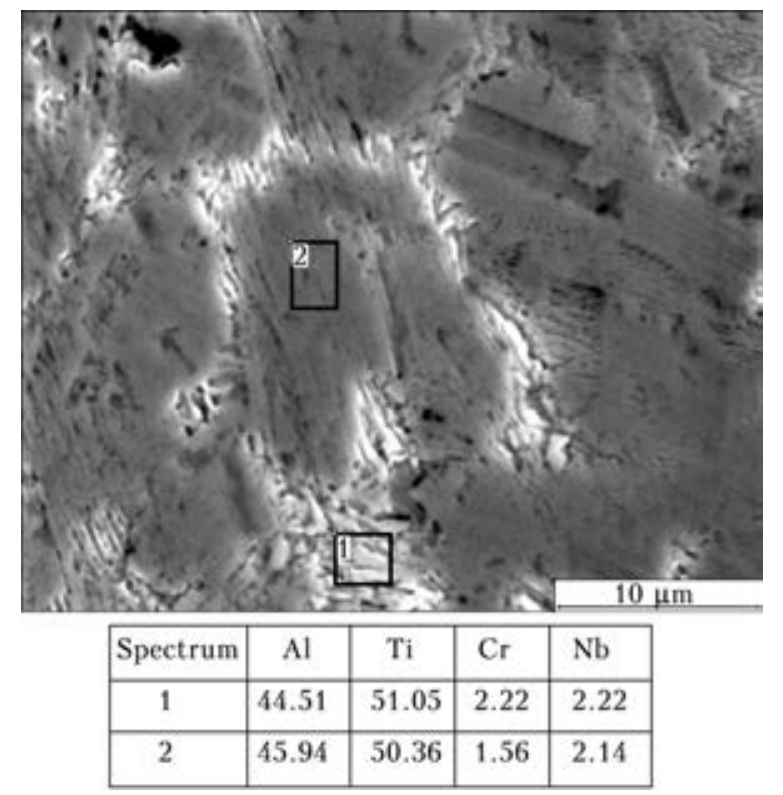

Figure 10. Microstructure and results of EDS-analysis of metal on joint line of $\mathrm{Ti}-47 \mathrm{Al}-2 \mathrm{Cr}-2 \mathrm{Nb}$ alloy at $\mathrm{RBW}$ with application of $\mathrm{Ti} / \mathrm{Co} \mathrm{NF}$ of $\delta=100 \mu \mathrm{m}$

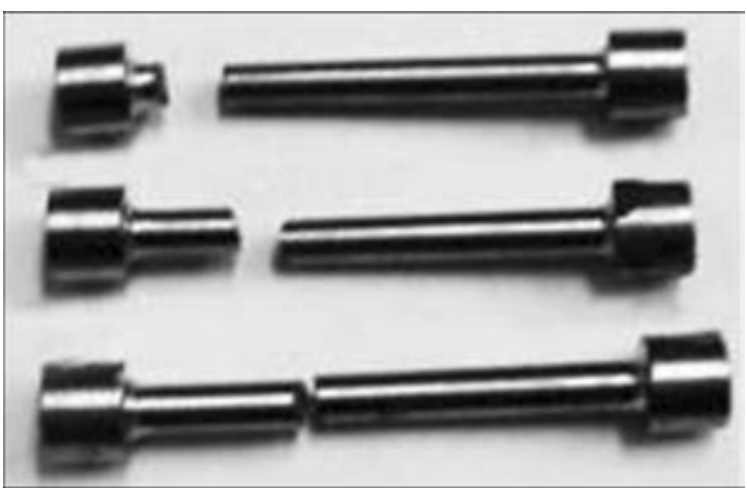

Figure 11. Samples of $\mathrm{Ti}-47 \mathrm{Al}-2 \mathrm{Cr}-2 \mathrm{Nb}$ alloy welded joints after rupture testing

billet initial metal. Performance of pre-heat treatment of samples being welded provides a slight lowering of hardness gradient in the joint zone.

To lower microhardness gradient and stabilize the structure of welded joint metal, heat treatment [17] is performed at the temperature corresponding to $(\alpha+\gamma)$-region of $\mathrm{Ti}-\mathrm{Al}$ constitutional diagram.

\section{Conclusions}

1. At $\mathrm{RBW}$ of $\mathrm{Ti}-47 \mathrm{Al}-2 \mathrm{Cr}-2 \mathrm{Nb}$ cast alloy without interlayer application, welding defects were observed in the entire studied range of technological parameter changing.

2 . In the zone of $\mathrm{Ti}-47 \mathrm{Al}-2 \mathrm{Cr}-2 \mathrm{Nb}$ alloy joints, produced by RBW with application of monolithic titanium foil, structural inhomogeneity is found in the form of continuous titanium interlayer and diffusion zone between the 
interlayer and alloy being welded, which contains linear porosity.

3. Application of multilayer $\mathrm{NF}$ of $\mathrm{Ti} / \mathrm{Al}$ system $(52 \mathrm{Ti}-48 \mathrm{Al}) 60-160 \mu \mathrm{m}$ thick at RBW of $\mathrm{Ti}-47 \mathrm{Al}-2 \mathrm{Cr}-2 \mathrm{Nb}$ alloy provides formation of defect-free joints. Fine-grained bimodal $\gamma / \gamma+\alpha_{2}$ structure forms in the joint zone, irrespective of $\mathrm{BM}$ initial structure. NF remains are present in the joint zone in the form of an interlayer of disperse $\gamma$-TiAl intermetallic, not containing any chromium, or niobium.

4. Formation of defect-free joints is provided at RBW with application of $\mathrm{NF}$ of $\mathrm{Ti} / \mathrm{Co}$ system $(75 \mathrm{Ti}-25 \mathrm{Co})$, and no chemical inhomogeneity in the form of foil transformation products is found in the butt. At rupture testing of joints, fracture runs through $\mathrm{BM} \mathrm{Ti}-47 \mathrm{Al}-2 \mathrm{Cr}-2 \mathrm{Nb}$ alloy.

5 . In all the considered cases, joint region of higher hardness coincides with the zone of structural changes, resulting from thermodeformational impact of RBW process.

1. Ivanov, V.I., Nochovnaya, V.A. (2007) Intermetallides on titanium base (analysis of state of the problem). Titan, 1, 44-48.

2. Polkin, I.S., Kolachev, B.A., Iliin, A.A. (1997) Titanium aluminides and alloys on their base. Tekhnol. Lyog. Splavov, 3, 32-39.

3. Dimiduk, D.M. (1995) Gamma titanium aluminides - An emerging materials technology. In: Gamma titanium aluminides: TMS'95 Ann. Meet. Proc. (Las Vegas), 3-20.

4. Ivanov, V.I., Yasinsky, K.K. (1996) Efficiency of application of heat-resistant alloys on the base of Ti3A and TiAl intermetallides for service at temperatures of $600-800{ }^{\circ} \mathrm{C}$ in aviation engineering. Tekhnol. Lyog. Splavov, 3, 7-12.

5. Pavlinich, S.P., Zajtsev, M.V. (2011) Application of intermetallic titanium alloys in casting of GTE components and blades with lightweight high-strength structures for aviation engines of new generation. Vestnik UfimGATU, 15(4), 200-202.

6. Arenas, M.F., Acoff, V.L. (2003) Analysis of gamma titanium aluminide welds produced by gas tungsten arc welding. Welding $J ., 5,110-115$

7. Patterson, R.A. et al. (1990) Titanium aluminide: Electron beam weldability. Ibid., 1, 39-44.

8. Zamkov, V.N., Velikoivanenko, E.A., Sabokar, V.K. et al. (2001) Selection of temperature of preheating of $\gamma$-titanium aluminide in electron beam welding. The Paton Welding J., 11, 17-20.

9. Yushtin, A.N., Zamkov, V.N., Sabokar, V.K. et al. (2001) Pressure welding of intermetallic alloy $\gamma$-TiAl. Ibid., 1, 33-37.

10. Miyashita, T., Hino, H. (1994) Friction welding characteristics of TiAl intermetallic compound. $J$. $J a^{-}$ pan Inst. Metals, 58(2), 215-220.

11. Baeslack, W.A., Threadgill, P.L., Nicholas, E.D. et al. (1996) Linear friction welding of $\mathrm{Ti}-48 \mathrm{Al}-2 \mathrm{Cr}-$ $2 \mathrm{Nb}$ (at.\%) titanium aluminide. In: Proc. of Titanium-95 Conf. on Science and Technology (Birmingham, UK, 22-26 Oct. 1995), 424-431.

12. Gam, G., Bohm, K.N., Kocak, M. (1999) Diffusionsschweissen fein gegossener Titanaluminide. Schweissen und Schneiden, 8, 470-475.

13. Nakao, Y., Shinozaki, K., Hamada, M. (1992) Diffusion bonding of intermetallic compound TiAl. In: Proc. of 3 rd Int. Conf. on Trends in Welding Research (Gattinburg, USA, June 1-5, 1992), 1057-1061.

14. Yan, P., Somekh, R.E., Wallach, E.R. (1992) Solid state bonding of TiAl with interlayers. Ibid., 1063-1067.

15. Duarte, L.I., Ramos, A.S., Vieira, M.F. et al. (2006) Solid-state diffusion bonding of $\gamma$-TiAl alloys using $\mathrm{Ti} / \mathrm{Al}$ thin films as interlayers. Intermetallics, $\mathbf{1 4}$, 1151-1156.

16. Ustinov, A.I., Falchenko, Yu.V., Ishchenko, A.Ya. et al. (2009) Producing permanent joints of $\gamma$-TiAl based alloys using nanolayered $\mathrm{Ti} / \mathrm{Al}$ interlayer by vacuum diffusion welding. The Paton Welding J., 1, 12-15.

17. Kharchenko, G.K., Ustinov, A.I., Falchenko, Yu.V. et al. (2011) Diffusion bonding of $\gamma$-TiAl base alloy in vacuum by using nanolayered interlayers. Ibid., 3, $2-6$

18. Ustinov, A.I., Falchenko, Yu.V., Melnichenko, T.V et al. (2012) Multilayer Ti/Al foils: Methods of producing, properties and application in pressure welding. Spetselektrometallurgiya, 1, 30-37.

19. Kharchenko, G.K., Mazanko, V.F., Ustinov, A.I. et al. (2009) Investigation of diffusion processes in welded joints of titanium aluminides (TiAl). Visnyk ChDTU, Series Tekhn. Nauky, 37, 117-119.

20. Kuchuk-Yatsenko, V.S., Shvets, V.I., Sakhatsky, A.G. et al. (2009) Features of resistance welding of titanium aluminides using nanolayered aluminium-titanium foils. The Paton Welding J., 3, 11-14.

21. Kuchuk-Yatsenko, S.I., Zyakhor, I.V., Zavertanny, M.S. (2015) Quality control of pressure welded joints using nanomaterials. Standartyz., Sertyfikats., Yakist, 1, 38-41. 